\title{
Nina Kristl
}

\section{SPREJEMANJE INFORMACIJSKO- KOMUNIKACIJSKE TEHNOLOGIJE Dejavniki in modeli}

\section{POVZETEK}

$V$ članku predstavljamo pomen sodobne tehnologije in njen vpliv na družbeni razvoj ter uporabo $v$ izobraževanju. Naša temeljna predpostavka je, da se bosta pogostost in kakovost uporabe izobraževalne tehnologije (najširše definirane) povečali s poznavanjem dejavnikov, ki vplivajo na njeno uporabo. $V$ besedilu tako opredelimo koncept informacijske družbe in prikažemo različna mnenja o vplivu sodobne informacijsko-komunikacijske tehnologije na družbo. E-izobraževanje kot razširjeno obliko izobraževanja umestimo $v$ kontekst informacijske družbe in predstavimo teorije sprejemanja tehnologije, na katerih temelji »enotna teorija sprejemanja in uporabe tehnologije«(UTAUT). Ugotavljamo, da imajo pri sprejemanju e-izobraževanja in drugih izobraževalnih tehnologijah glavno vlogo ožje socialno okolje, psihološki dejavniki in tehnične značilnosti orodja, zato morajo biti ukrepi za spodbujanje večje uporabe usmerjeni na eno od teh področij. Eden od sklepov pričujoče analize je razširitev modelov sprejemanja tehnologije s pedagoškimi vidiki e-izobraževanja, ki so pri klasičnih modelih povsem zanemarjeni.

Ključne besede: informacijska družba, e-izobraževanje, spletno učno okolje, enotna teorija sprejemanja in uporabe tehnologije

\section{ADOPTION AND USE OF THE INFORMATION AND COMMUNICATIONS TECHNOLOGY - ABSTRACT}

The paper examines the importance of modern technology, its impact on the social development, and its use in education. Our basic assumption is that the frequency and quality of the use of educational technologies (broadly defined) will increase with the knowledge of the factors that affect its use. In the article we also define the concept of the information society, and examine different views on the impact of modern information and communications technologies on the society. We describe e-learning as a widespread form of education in the context of the information society, and introduce the theory of technology acceptance, on which the "Unified theory of acceptance and use of technology" (UTAUT) is founded. We find that in the adopting of e-learning and other educational technologies a key role may be played by the immediate social environment, psychological factors and technical features of the tool. These factors should therefore be taken into consideration when trying to encourage a 
wider use of these tools. One of the conclusions of the analysis is that the models of technology adoption could be extended with inclusion of the pedagogical aspects of e-learning, which are completely neglected in the traditional models.

Keywords: information society, e-learning, on-line learning, unified theory of acceptance and use of technology

\section{UVOD}

Nagel razvoj informacijsko-komunikacijske tehnologije (IKT) je posegel tudi na področje izobraževanja, s tem pa so se spremenili oblike učenja ter načini podajanja znanja in komunikacije med udeleženci izobraževalnega procesa. Ker se je e-izobraževanje uveljavilo na mnogih precej različnih področjih, so tudi definicije e-izobraževanja zelo različne, predvsem pa neenotne. E-izobraževanje je pogosto (Nicholson, 2007) opredeljeno kot nova oblika izobraževanja, ki uporablja internet in nove tehnologije za raznolike izobraževalne prakse. Slednje so praviloma interaktivne, uporabljajo različne učne materiale in programe $\mathrm{z}$ namenom prilagajanja učenja različnim izobraževalnim praksam. Opredelitve e-izobraževanja so pogosto tudi precej ohlapne (Bregar, Zagmajster in Radovan, 2010), saj kot tako definirajo »izobraževanje, pri katerem se uporablja IKT«, pa najsi bo to spletno učenje, virtualne učilnice, podajanje vsebin prek interneta, zvočne in video vsebine ali izobraževalne oddaje. Vzrok za raznolikost opredelitev e-izobraževanja Nicholson (2007) pripiše dejstvu, da ima e-izobraževanje različne pojavne oblike, odvisno od dejavnosti, v kateri se uveljavi - podjetništvo, vojska, storitveni sektor ali visokošolsko izobraževanje. Če se osredotočimo na slednje, postane jasno, da e-izobraževanje v sistemu visokošolskega izobraževanja ne more označevati le tistih izobraževalnih praks, ki so podprte z IKT, temveč mora izpolnjevati tudi temeljne cilje izobraževanja, tj. razvoj metakognitivnih sposobnosti in refleksivnega ter sodelovalnega učenja (Campbell v Keengwe in Kidd, 2010).

Bates (2005) e-izobraževanje postavi v širši družbeni kontekst ter pojasnilo za njegovo močno ekspanzijo v zadnjih desetletjih najde v podpori, ki so mu jo dale države. Namreč, ekonomsko razvite družbe so $\mathrm{v}$ e-izobraževanju prepoznale določene priložnosti, med katere Bates uvrsti večjo ekonomsko konkurenčnost držav v smislu razvoja visokoproduktivnih in na znanju temelječih industrij, katerih učinek je globalizacija izobraževalnih storitev in produktov ter večja kakovost znanja (Bates, 2005). Stava na kakovostnejše znanje, pridobljeno z e-izobraževanjem, izhaja iz prepričanja, da to ponuja več možnosti za udejanjanje konstruktivističnih načel izobraževanja kot klasični, »transmisijski « način izobraževanja. Pri tem pa je vendarle treba opozoriti, da uporaba tehnologije sama po sebi ne more biti vnaprejšnje zagotovilo za kakovostnejše pridobivanje znanja, saj gre le za možnosti, ki jih ponuja. Pomembno vlogo pri spodbujanju ekspanzije e-izobraževanja ima po mnenju Batesa (prav tam) tudi večja stroškovna učinkovitost, saj naj bi e-izobraževanje dolgoročno znižalo stroške dela s tehnološko nadomestitvijo zaposlenih, izobraževanje pa ponudilo širšim množicam, kot to zmore konvencionalni izobraževalni sistem, čeprav so, kot opozarja Bates (prav tam, str. 12), takšna pričakovanja morda še prezgodnja, saj ni 
na voljo relevantnih analiz stroškovne učinkovitosti e-izobraževanja. Po mnenju Batesa v razvitih državah tudi verjamejo, da lahko e-izobraževanje precej pripomore $\mathrm{h}$ komercializaciji izobraževanja. Namreč, izobraževalne institucije ob pritiskih, da razpršijo svoje vire financiranja, vidijo v e-izobraževanju potencialni vir svojega financiranja. Med priložnosti, ki jih ponuja e-izobraževanje, pa sodi tudi večja dostopnost izobraževanja, najprej v geografskem smislu, in sicer, da imajo do e-izobraževanja dostop tudi tisti, ki živijo na redko poseljenih območjih, kjer praviloma ni široke ponudbe konvencionalnih oblik izobraževanja; hkrati pa je dostopnost izobraževanja večja tudi v družbenem smislu, saj ponuja osebam, ki se iz osebnih ali ekonomskih razlogov ne morejo vključiti v konvencionalne oblike izobraževanja, večje možnosti za pridobitev izobrazbe.

Mnenju, da IKT »odpira pot do znanja vsem ljudem«, se pridružuje tudi Ana Krajnc (2008, str. 31), saj pravi, da z uporabo interneta v izobraževanju premagujemo centralizacijo izobraževalne ponudbe, s tem pa tudi centralizacijo možnosti za učenje. V širši dostopnosti znanja vidi možnost krepitve človeškega in socialnega kapitala. Vir slednjega so po njenem tako formalne institucije kot civilna družba; socialni kapital pa vpliva na kakovost dela in življenja ljudi. Dalje pa kot priložnost, ki jo prinaša e-izobraževanje, navaja še ustrezen odziv na stopnjevanje zahtevnosti dela in življenja v industrijski družbi, ki terja večjo usposobljenost in višjo stopnjo razvitosti prebivalstva. Potrebe industrijske družbe po z ustreznim znanjem opremljenem prebivalstvu se ne ustavijo le pri mlajših generacijah, temveč je treba dodatno izobraziti tudi odrasle in ljudi v tretjem življenjskem obdobju (prav tam). V tem smislu ima e-izobraževanje pomembno vlogo $\mathrm{v}$ družbi znanja, ki si prizadeva za uresničevanje paradigme vseživljenjskega učenja oziroma z besedami Batesa (2005, str. 11): »e-izobraževanje [...] je idealna metoda vseživljenjskega učenja $\ll$.

\section{VPLIV IKT NA DRUŽBO}

Razlage vpliva IKT na družbo in sprememb, ki so se zgodile z ekspanzijo IKT, so številne. V nadaljevanju so predstavljeni trije teoretični pristopi, ki jih je Fischer (1992) identificiral glede na obstoječe teorije obravnave razmerja med družbo in tehnologijo. Najprej sta predstavljeni dve nasprotujoči si sociotehnološki teoriji, ki sta tudi najbolj razširjeni, to sta tehnološki determinizem in simptomatični pristop. Prva obravnava družbo kot odvisno od vpliva tehnologije, druga pa, nasprotno, predpostavlja, da je družba tista, ki vpliva na tehnologijo in jo oblikuje. Tretja perspektiva, ki jo Fischer (prav tam) poimenuje socialni konstruktivizem, prinaša alternativni pogled na predhodni deterministični teoriji in v ospredje postavi posameznikovo aktivno vlogo pri lastnem delovanju, torej uporabi tehnologije. Pri sociotehnoloških teorijah gre torej za vprašanje razmerja med uporabniki in tehnologijo ter tehnološko posredovano komunikacijo.

\section{Tehnološki determinizem}

Tehnološki determinizem kot redukcionistična teorija reducira »specifičnost komunikacijske prakse, ki poteka prek nekega komunikacijskega medija, na tehnološke lastnosti 
samega medija « (Chandler v Škerlep 1998, str. 25). Gre torej za prepričanje, da vsak IKT določa (determinira) komunikacijsko prakso, saj, kot navaja Škerlep (prav tam), vsaka tehnologija komunikacijski praksi, ki poteka prek nje, postavlja možnosti in omejitve, kar kaže na to, da jo v neki meri pogojuje. Fischer (1992) opozarja, da teorije tehnološkega determinizma obravnavajo družbo in tehnologijo kot dve ločeni sferi, ki skupaj tvorita družbeno realnost.

Med avtorje, ki jih uvrščamo med tehnološke deterministe, spada McLuhan (1964), ki poudarja, da so nove tehnologije spremenile našo percepcijo družbe. Ko govori o vplivu tehnologije na družbo, ima v mislih tako njen fizični kot tudi družbeni učinek. Dejanski učinek nove tehnologije pa je odvisen le od medija samega, ne pa tudi od vsebine, ki jo prinaša. Zgodovinsko gledano je razvoj družbe potekal prek in zaradi razvoja tehnologije, in ne obratno. Kot opozarja Škerlep (1998), je nevarnost take interpretacije v le delni veljavnosti izhodiščne predpostavke, saj komunikacijska tehnologija le delno določa komunikacijsko prakso.

Tehnologija, ki sproži od družbe neodvisne, nevtralne in avtonomne spremembe, v teorijah tehnološkega determinizma nastopa kot neodvisna spremenljivka (Chandler, 1995). Chandler (prav tam) navaja še obravnavo tehnologije kot eksogene in samonadzorne moči $\mathrm{v}$ teorijah tehnološkega determinizma, v katerih tehnologija nikoli ne nastopa kot družbeni produkt ali vsaj kot njen integralni del. Prepričanje o tem, da je razvoj tehnologije neodvisen od človeškega nadzora, Chandler (prav tam) utemeljuje s pojavom nepredvidljivih stranskih učinkov, ki jih ima lahko tehnološki razvoj.

\section{Simptomatični pristop}

Simptomatični pristop, imenovan tudi družbeni determinizem (Haralambos in Holborn, 2005), je protipol predhodno obravnavanemu tehnološkemu determinizmu, saj izhaja iz nasprotnega stališča kot slednji, in sicer, da je tehnologija, kot zapiše Fischer (1992), izraz družbe, ne pa da vdira vanjo, kot predpostavljajo teorije tehnološkega determinizma. Z besedami Williamsa (2003) simptomatični pristop izhaja iz prepričanja, da je razvoj tehnologij simptom sprememb v družbi. Družba je torej tista, ki vpliva na tehnološke spremembe, na to, kako se tehnologija razvija, uporablja in kakšen je odnos do nje (Haralambos in Holborn, 2005).

Dalje Fischer (1992) identificira še prepričanje o homogenosti načinov uporabe tehnologije v družbi ter tudi učinkov uporabe kot značilnosti simptomatične paradigme. Pravzaprav je učinek uporabe tehnologije dojet kot v izhodišču racionalen in predvidljiv, prav takšna pa je tudi uporaba tehnologije. Dojemanje učinka uporabe tehnologije kot homogenega, za vse ljudi enakega, implicitno predpostavlja, da tehnologije delujejo ločeno od družbe in nanjo nimajo vpliva. Družba je torej tista sila, ki ustvari tehnološki razvoj in s tem tehnologije, te pa v svojem bistvu niso nič drugega kot manifestacija duha nekega časa. Duh časa v sodobni družbi Fischer (prav tam, str. 13) opredeli kot »naraščajočo racionalizacijo življenja, ki jo spremljajo mehanizacija, nepristnost in podobne korenite spremembe«. Tehnologija je v tej perspektivi izraz silnic, vgrajenih v 
družbeno in kulturno vedenje; pri tem pa obstaja tveganje, zanemarjenja raznolikosti načinov manifestacije tehnologije ter s tem napačnega predpostavljanja koherentnega in konsistentnega oblikovanja tehnologije kot celote, na kar opozarja Fischer (prav tam). Sklenemo lahko z Williamsovimi (2003, str. 133) besedami, da »medtem ko moramo zavrniti tehnološki determinizem, moramo paziti, da ga ne nadomestimo s stališčem o determiniranosti tehnologije $\ll$.

\section{Socialni konstruktivizem}

Pri obeh doslej obravnavanih pristopih je šlo za dojemanje tehnologije in njenega razvoja kot ločenih od družbe. Socialni konstruktivizem ponudi pogled na razmerje med tehnologijo in družbo, ki presega umetno ustvarjeni prepad med njima. Namreč, kot zapiše Williams (2003, str. 138), determiniranost ni le ena sila, temveč »proces, v katerem dejavniki determiniranosti [...] postavljajo meje in izvajajo pritisk, vendar jih ni možno $\mathrm{v}$ celoti nadzorovati niti napovedovati učinkov kompleksnih aktivnosti znotraj teh meja in pritiskov «. $Z$ drugimi besedami, tehnologija se razvije $\mathrm{z}$ določenim namenom in za aktivnosti, ki so vnaprej znane, prisvajanje tehnologije pa nato spremeni družbene procese. Tehnologija se tako zmeraj ustvari in prisvaja v družbenem kontekstu. Zaradi tega razloga socialni konstruktivizem temelji na prepričanju, da sta družba in tehnologija medsebojno prepleteni, med njima poteka interakcija, pri čemer pa ni možno predvideti učinka tega medsebojnega delovanja. Učinek je namreč zmeraj rezultat družbene akcije (prav tam).

Podobno tudi Fischer (1992) meni, da ima posameznik ali skupina s svojimi cilji bolj aktivno vlogo pri ustvarjanju učinkov tehnologije na družbo in nasprotno, saj, kot pravi (prav tam, str. 17), »nanje ne vpliva niti zunanja sila niti niso nezavedne figure duha časa«, kar pomeni, da posamezniki niso pasivni sprejemniki tehnoloških sprememb, temveč jih aktivno konstruirajo skozi materialne prakse in pomene. Z besedami Škerlepa (1998) so uporabniki IKT tisti, ki svojo komunikacijsko prakso določajo s svojim izkustvom, preferencami in cilji.

Teorije socialnega konstruktivizma lahko po predlogu Bijkerja, Highesa in Pincha (1987) razvrstimo v tri skupine: družbena konstrukcija tehnologije, sistemske teorije in teorije akterjev v mreži.

Teorije, ki sodijo v prvo skupino, sta Pinch in Bijker (1984) opredelila kot tiste, ki vidijo razvoj tehnologije kot interaktivni proces ali diskurz med tehnologi in zainteresiranimi družbenimi skupinami. Tehnologija je torej socialno konstruirana, pri tem pa imajo ključno vlogo zainteresirane družbene skupine, ki so lahko znanstveniki, politiki, podjetniki, otroci ipd., in njihove interpretacije tehnologije. Posamezniki ali skupine artefaktom pripisujejo določene pomene in interpretacije, skozi te pa nato usmerjajo razvoj tehnologije. V tem smislu je razvoj tehnologije interaktivni sociotehnološki proces, pri katerem na eni strani tehnologije in inovacije organizirajo življenja posameznikov, na drugi strani pa so relevantne družbene skupine tiste, ki skozi ustvarjanje pomenov določajo razvoj tehnologije. 
Opredelitev druge skupine teorij, sistemskih teorij, Bijker in drugi (1987) oprejo na Hughesovo razumevanje tehnološke inovacije in stabilizacije, iz katerega izhaja, da tistih, ki »oblikujejo artefakte, slednji sami po sebi ne zanimajo, temveč morajo upoštevati način, na katerega se ti artefakti nanašajo na družbene, politične in znanstvene dejavnike« (prav tam, str. 112), pri čemer so vsi ti dejavniki medsebojno povezani. Tehnološke inovacije so v tem kontekstu dojete kot sistemski gradniki, zato Hughes (v Petrovčič, 2011) trdi, da bi se bilo narobe osredotočati na družbeno konstrukcijo artefaktov oziroma na vlogo posameznega artefakta $v$ družbi, saj tako spregledamo družbeni sistem kot celoto, kar pa lahko vodi do napačnih sklepov. Sistem opiše (prav tam) kot sociotehnološke entitete, ki težijo h gradnji hierarhične strukture. Hierarhična struktura pa je dalje rezultat večfaznega procesa razvoja tehnologije, na katerega ne vplivajo le značilnosti tehnologije, temveč tudi družbene, politične, kulturne in organizacijske okoliščine (prav tam).

Tretja skupina teorij, imenovana teorije akterjev v mreži (angl. actor-network), pomeni kritiko teorij družbene konstrukcije tehnologije, in sicer v tistem delu, kjer slednje dajejo preveliko pomembnost družbenim strukturam pri njihovem usmerjanju razvoja tehnologije. Poudarek teorij akterjev v mreži je po mnenju Petrovčiča (2011) na vzajemnosti konstituiranja odnosa med tehnologijo in družbo. Callon (prav tam, str. 78) opredeli izhodiščno predpostavko teh teorij z besedami: »Akterje v mrežah ni možno reducirati niti na akterje kot take, niti na mrežo samo. Kot mreže so tudi ti (akterji v mrežah, op.) sestavljeni iz serije heterogenih elementov, živih in neživih, ki so za neko obdobje medsebojno povezani.« Z besedami Petrovčiča (prav tam) te teorije temeljijo na prepričanju, da je uporaba tehnologij, kot tudi materialne in simbolične značilnosti, rezultat nenehnega transformiranja mrež, v katerih tako živi kot neživi dejavniki enako prispevajo k razvoju tehnoloških mrež. Kot je dejal Pannabecker (1991), je bistvena prednost tega pristopa v preseganju arbitrarno določenih razlik in kategorij, ki pogosto poenostavljajo kompleksnost tehnologij in vsiljujejo meje posameznim znanostim, ki se ukvarjajo s tem področjem. Mreže so v tem pristopu torej koherentna celota, znotraj katere poteka mnoštvo razmerij in odnosov, ki se morajo nenehno izvajati, da bi se lahko mreža ohranila.

Predstavljene teorije ponujajo konceptualni okvir, skozi katerega lahko mislimo, analiziramo in razlagamo dejanske in opažene družbene spremembe. Za nas so najpomembnejše tiste spremembe, ki se nanašajo na izobraževanje in učenje v širšem smislu, s čimer se tudi ukvarjamo v nadaljevanju.

\section{Digitalne razlike}

Povečan dostop in demokratizacijo učenja prek novih tehnologij Radovan (2012) označuje kot obljubo, ki se še ni uresničila v želeni meri. Dalje opozarja, da »so lahko nove digitalne tehnologije vir novih neenakosti in marginalizacije nekaterih družbenih skupin « (prav tam, str. 38), saj kljub temu, da se dostop do novih tehnologij izboljšuje, se to dogaja pretežno $v$ razvitem svetu, države $v$ razvoju in nerazvite države pa ostajajo pri tem izključene. 
Gre za t. i. digitalne razlike (angl. digital divide), ki označujejo delitev na tiste, ki imajo dostop do novih tehnologij, in tiste, ki ga nimajo, ter delitev na tiste, ki znajo uporabljati nove tehnologije, in tiste, ki jih ne znajo.

Kot opozarjata Dinevski in Radovan (2013), ima koncept digitalnih razlik več dimenzij. Po P. Norris (2001) lahko digitalne razlike razvrstimo v tri dimenzije: prva se nanaša na globalno razhajanje med razvitimi industrijskimi državami in državami v razvoju, druga dimenzija obsega socialne razlike $\mathrm{v}$ razvitih državah, in sicer med tistimi, ki so informacijsko pismeni, in tistimi, ki imajo manj informacijskega znanja; tretja dimenzija pa zajema razlike, ki obstajajo med uporabniki in neuporabniki digitalnih tehnologij, torej med tistimi, ki imajo možnost mobilizacije in participacije v javnem življenju prek digitalnih tehnologij, in tistimi, ki te možnosti nimajo.

Van Dijk (2005, str. 21) neenakosti v dostopu, ki jih povzročajo nove tehnologije, opredeljuje v štirih zaporednih stopnjah:

- motivacijski dostop: posameznikova motivacija, da sprejme, usvoji in uporabi tehnologijo,

- materialni ali fizični dostop: imeti fizični dostop do novih tehnologij, fizično posedovati tehnologijo,

- razlike $v$ sposobnostih: se nanašajo na operativne (obvladovanje tehnologije), informacijske (sposobnost iskanja, selekcioniranja in procesiranja informacij) in strateške sposobnosti (uporaba tehnologije $\mathrm{z}$ določenim namenom),

- razlike v dostopu do uporabe: se nanašajo na razlike $\mathrm{v}$ času, $\mathrm{v}$ katerem uporabnik uporablja tehnologijo, $v$ dejanski uporabi, raznolikosti uporabe, širokopasovni in kreativni uporabi.

Van Dijk (prav tam, str. 45) k temu dodaja, da je koncept digitalnih razlik mnogo širši in da digitalnih razlik ne bomo presegli zgolj tako, da bomo posamezniku dali računalnik in ga povezali $\mathrm{v}$ internet.

V kontekstu digitalnih razlik na področju e-izobraževanja pa moramo biti pozorni tudi na kakovost učnih vsebin, uporabljenih v procesu e-izobraževanja. Kakovost e-izobraževanja sicer ni predmet tega članka, a je vendarle treba opozoriti tudi na to, saj je dostop do kakovostnih izobraževalnih vsebin prav tako eden izmed vidikov digitalnih razlik. Radovan (2012) zapiše, da je zagotavljanje prosto dostopnih učnih virov večplasten politični in družbeni izziv, saj ne ustvarja neposrednega dobička, vendar pa pomembno vpliva na demokratizacijo izobraževanja. Po Gesserju (v Radovan, 2012) so značilnosti prosto dostopnih učnih virov, da so brezplačni za vse udeležence izobraževanja, da se njihova vsebina lahko v izobraževalne namene spreminja in preoblikuje ter da so vmesniki za programiranje aplikacij odprtokodni.

\section{SPREJEMANJE IN UPORABA IKT}

Uspešnost uvajanja informacijsko-komunikacijske tehnologije v vseživljenjsko učenje in organizacije, tudi izobraževalne, je neizogibno povezana s sprejemanjem IKT 
in pripravljenostjo za uporabo IKT na strani uporabnikov računalniških ali spletnih tehnologij. Dillon in Moriss (1996) definirata pojem uporabniške sprejetosti (angl. user acceptance) kot »nazorno pripravljenost (skupine uporabnikov) uporabiti informacijsko tehnologijo za izvedbo opravila, za katero je namenjena«. Uporabniška sprejetost torej pomeni, da je posameznikovo mnenje naklonjeno sprejemanju tehnologije z namenom njene uporabe (Colby, 2002). Tehnološko pripravljenost (angl. technology readiness) pa Colby (prav tam) opredeli kot konstrukt, sestavljen iz štirih dimenzij: optimizem, inovativnost, negotovost in neugodje, pri čemer prvi dve dimenziji delujeta kot spodbujevalca tehnološke pripravljenosti in sprejemanja tehnologije, zadnji dve dimenziji pa imata nanju zaviralni vpliv.

Slika 1: Dejavniki vpliva na tehnološko pripravljenost

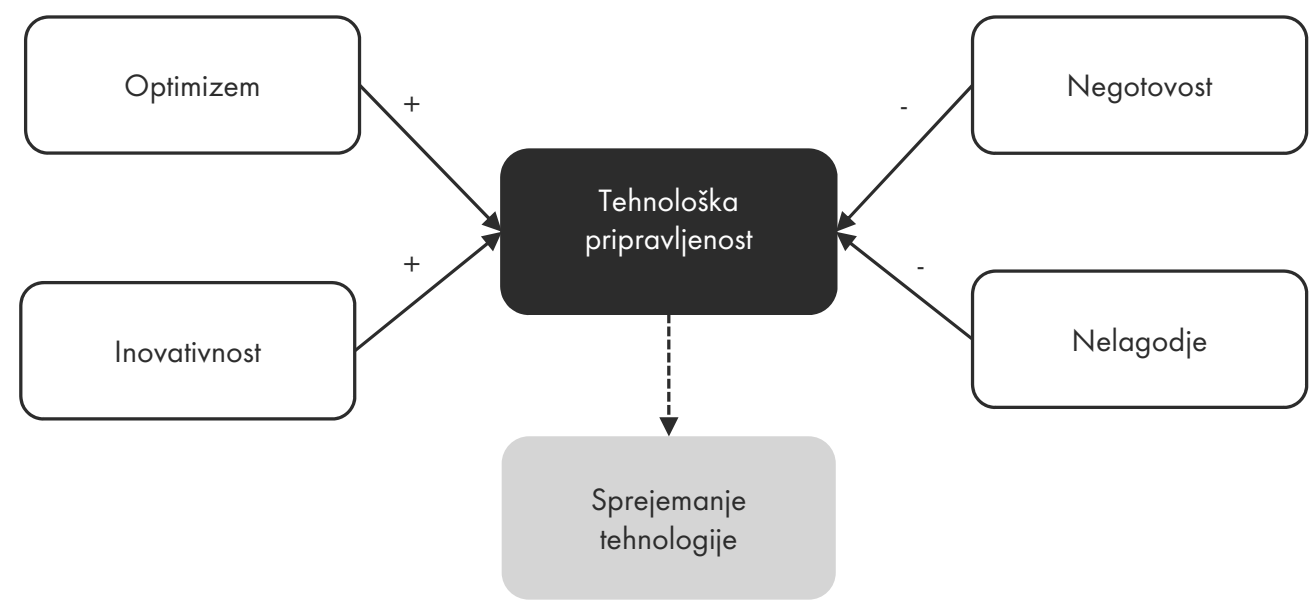

Vir: Colby (2002)

Optimizem kot dejavnik spodbujanja Colby (2002) opredeli kot »stopnjo zaupanja posameznika v prednosti tehnologije«, pri čemer je tehnologija dojeta kot sredstvo za »nadzor in fleksibilnost « posameznikove dejavnosti; skupaj z inovativnostjo, ki je opredeljena kot »stopnja posameznikove naklonjenosti do raziskovanja in eksperimentiranja z novimi tehnologijami«, pa sta pomembni determinanti posameznikove pripravljenosti za samoizobraževanje in raziskovanje novih tehnologij (prav tam). Na drugi strani pa kot zaviralca tehnološke pripravljenosti delujeta dejavnika negotovost $\mathrm{v}$ smislu pomanjkanja zaupanja $\mathrm{v}$ varnost in zaščito posameznika ter nelagodje kot pomanjkanje nadzora nad tehnologijo in strah pred njo. Vsak izmed navedenih dejavnikov pomembno vpliva na tehnološko pripravljenost in posledično na samo sprejemanje tehnologije, vendar pa, kot že rečeno, gre pri tehnološki pripravljenosti za stopnjo izraženosti posamezne dimenzije, ki slednjo opredeljuje, in ne za prisotnost oziroma odsotnost posameznih dimenzij, zato govorimo o večji ali manjši izraženosti posamezne dimenzije. 
Parasuraman (2000) je v kontekstu teorije o tehnološki pripravljenosti razvil indeks tehnološke pripravljenosti TRI (Technology Readiness Index) in s tem merski instrument za merjenje sprejemanja tehnologije na podlagi merjenja posameznih dimenzij, ki so se izkazale kot medsebojno relativno neodvisne. Vpeljava indeksa tehnološke pripravljenosti je pokazala, da dotedanje prepričanje o sprejemanju in uporabi tehnologije kot linearnem, kontinuiranem procesu prehajanja skozi faze uporabniške naprednosti ni ustrezno, saj je sprejemanje tehnologije kompleksnejši proces. V kontekstu sprejemanja tehnologije je zato ustrezneje govoriti o tipih uporabnikov; segmentacijska analiza na podlagi stopnje izraženosti posamezne dimenzije tehnološke pripravljenosti pa pokaže, da obstaja pet različnih tipov uporabnikov tehnologije (prav tam).

Tabela 1: Značilnosti posameznih tipov uporabnikov

\begin{tabular}{|l|l|l|l|l|}
\hline Tip uporabnika & $\begin{array}{l}\text { Stopnja } \\
\text { optimizma }\end{array}$ & $\begin{array}{l}\text { Stopnja } \\
\text { inovativnosti }\end{array}$ & $\begin{array}{l}\text { Stopnja } \\
\text { nelagodja }\end{array}$ & $\begin{array}{l}\text { Stopnja } \\
\text { negotovosti }\end{array}$ \\
\hline Raziskovalci & visoka & visoka & nizka & nizka \\
\hline Začetniki & visoka & visoka & visoka & visoka \\
\hline Skeptiki & nizka & nizka & nizka & nizka \\
\hline Paranoiki & visoka & nizka & visoka & visoka \\
\hline Počasneži & nizka & nizka & visoka & visoka \\
\hline
\end{tabular}

Vir: Colby (2002)

Zgornja segmentacija uporabnikov je pomembna predvsem zaradi tega, ker nam pove, da imamo kot posamezniki do tehnologije različen odnos in je zato uspešnost uvajanja novih tehnologij v organizacije odvisna tudi od stališč posameznika in ne le od pričakovanih koristi, ki izhajajo iz uporabe določene tehnologije, stališča pa se sicer - kot je razvidno iz v nadaljevanju predstavljenih modelov - pojavljajo kot osrednji element teorij sprejemanja informacijske tehnologije.

\section{Teorije in modeli sprejemanja IKT}

Teorij in na njih temelječih modelov sprejemanja in uporabe tehnologije je nepregledno veliko, zato so na tem mestu predstavljene le najpomembnejše izmed njih oziroma tiste, ki se najpogosteje uporabljajo pri raziskovanju sprejemanja tehnologije (Dillon in Morris, 1996; Stefl Mabry, 1999) in je na njih utemeljena Venkatesheva (2003) enotna teorija sprejemanja in uporabe tehnologije - UTAUT (angl. The Unified Theory of Acceptance and Use of Technology).

Za teorije, ki se ukvarjajo s sprejemanjem tehnologije, je značilno, da so večdisciplinarne (Dillon in Morris, 1996), poskušajo pa odgovoriti na vprašanje, kako in zakaj uporabniki bodisi sprejemajo bodisi zavračajo nove tehnologije (Stefl Mabry, 1999). Njihov večdisciplinarni pristop se poleg tehnološkega vidika (značilnosti tehnologije, enostavnost oziroma zapletenost uporabe ipd.) osredotoča še na sociološki (vpliv ožjega in širšega 
okolja na sprejemanje, prostovoljnost uporabe ipd.) in psihološki (pričakovana koristnost uporabe, pričakovana enostavnost uporabe ipd.) vidik.

\section{Teorija širjenja inovacij}

Temeljni namen teorije širjenja inovacij (angl. The Innovation Diffusion Theory $I D T$ ) je prikaz premikanja neke inovacije od stopnje invencije do široke uporabe (Dillon in Morris, 1996), kjer se izraz inovacija nanaša na idejo, ki je bila za posameznika ali družbo dotlej nepoznana. Rogers (2003) navaja štiri elemente, ki vplivajo na širjenje nove ideje: značilnost same inovacije, komunikacijski kanali, prek katerih deluje, čas širjenja in družbeni sistem. Širjenje inovacije je tako »proces, v katerem inovacija skozi določene komunikacijske kanale in v nekem času doseže člane določenega družbenega sistema« (prav tam, str. 5). Za napovedovanje in pojasnjevanje stopnje širjenja inovacij pri posamezniku Rogers (prav tam) opredeli pet determinant (glej Tabela 2), pri čemer ima lahko že vsaka posamezna determinanta samostojen učinek na hitrost širjenja.

Tabela 2: Determinante modela za pojasnjevanje širjenja inovacij

\begin{tabular}{|l|l|}
\hline Determinanta & Opis \\
\hline $\begin{array}{l}\text { Relativna prednost } \\
\text { (relative advantage) }\end{array}$ & $\begin{array}{l}\text { Subjektivno občutenje inovacije kot tiste, ki prinaša prednost (je izboljšana) od } \\
\text { predhodne generacije }\end{array}$ \\
\hline $\begin{array}{l}\text { Združliivost } \\
\text { (compatibility) }\end{array}$ & $\begin{array}{l}\text { Stopnja, do katere je inovacija združljiva s posameznikovimi vrednotami, potre- } \\
\text { bami in predhodnimi izkušnjami }\end{array}$ \\
\hline $\begin{array}{l}\text { Zapletenost } \\
\text { (complexity) }\end{array}$ & $\begin{array}{l}\text { Stopnja, do katere je inovacija dojeta kot zapletena za uporabo; zapletenost je } \\
\text { premo sorazmerna s časom za usvojitev inovacije }\end{array}$ \\
\hline $\begin{array}{l}\text { Možnost preizkuša- } \\
\text { nja (trialability) }\end{array}$ & $\begin{array}{l}\text { Stopnja, do katere lahko posameznik inovacijo preizkuša; več ko je možnosti } \\
\text { preizkušanja, krajši je čas posvojitve inovacije }\end{array}$ \\
\hline $\begin{array}{l}\text { Opaznost } \\
\text { (observability) }\end{array}$ & $\begin{array}{l}\text { Obseg opaznosti inovacije za tiste, ki je še ne poznajo; bolj ko jim je vidna, } \\
\text { večja je verjetnost, da jo bodo posvojili }\end{array}$ \\
\hline
\end{tabular}

Vir: Rogers (2003)

Čeprav klasična teorija širjenja inovacij ne daje zadovoljive razlage za sprejemanje novega IKT-orodja na ravni posameznika, pa kljub temu ponuja širši kontekst njegovega posvajanja, hkrati pa je tudi pomembno vplivala na kasnejši razvoj teorij sprejemanja tehnologije.

\section{Teorija utemeljene akcije}

Teorija utemeljene akcije (angl. Theory of Reasoned Action - TRA), katere utemeljitelja sta Fishbein in Ajzen (1975), predpostavlja, da na vedenje posameznika vpliva namera za udejanjanje nekega vedenja. Zaradi obravnave vedenja posameznika, ki je jedro te teorije, se uvršča med sociopsihološke teorije (Dillon in Morris, 1996). Avtorja (1975) z njo opredelita razmerje med stališči posameznika, njegovim odnosom do dejanja/ 
vedenja, normami, namero in samim udejanjanjem vedenja ter s tem pojasnjujeta naklonjenost oziroma sprejemanje tistega, česar sprejemanje se raziskuje.

Slika 2: Model teorije utemeljene akcije

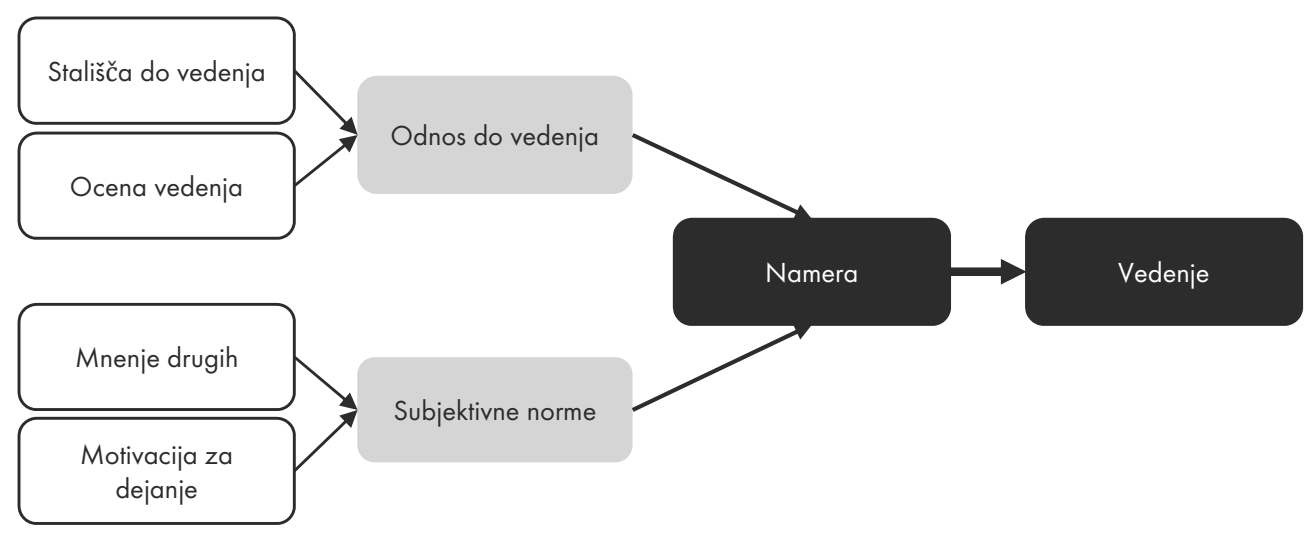

Vir: Fishbein in Aizen (1975, str. 16)

Posameznikovo dejansko vedenje sta torej opredelila (glej Slika 2) kot posledico namere dejanja (angl. behavior intention), ta pa je seštevek posameznikovega odnosa do vedenja kot občutenja slednjega in subjektivnih norm, definiranih z vplivom širšega ali ožjega socialnega okolja in motivacije za dejanje, pri čemer je seštevek obtežen s težo posamezne dimenzije za posameznika.

Kot pokažejo Sheppard, Hartwick in Warshaw (1988) v svoji metaanalizi uporabnosti teorije utemeljene akcije, se ta dobro obnese $\mathrm{v}$ napovedovanju odločitve posameznika, ko ima ta na voljo več izbir, pa tudi takrat, ko je njegovo vedenje neprostovoljno, kar je še posebej pomembno, ko raziskujemo sprejemanje tehnologije v organizacijah, kjer odločitev za uporabo tehnologije ni prostovoljna, saj je tako teža vpliva zunanjega okolja in motivacije za dejanje večja kot sicer.

\section{Teorija načrtovanega vedenja}

Teorija načrtovanega vedenja (angl. Theory of planned behavior - TPB) predpostavlja, da so »stališča, subjektivne norme in zaznani vedenjski nadzor neposredne determinante namer, ki posledično vplivajo na vedenje « (Stefl Mabry, 1999, str. 84). Ta teorija temelji na teoriji utemeljene akcije, a v ospredje razlage postavi koncept zaznanega vedenjskega nadzora (angl. perceived behavioral control), ki ga Taylor in Todd (v Stefl Mabry, 1999) vidita kot posledico lastne zmožnosti, razpoložljivih virov in razpoložljive tehnologije, kar kaže na to, da je pri tej teoriji pomembna predvsem posameznikova ocena lastne zmožnosti v danih okoliščinah, ki skupaj z dejanskim nadzorom nad vedenjem in namero določa dejansko vedenje (Ajzen, 1991). 
Slika 3: Model teorije načrtovanega vedenja

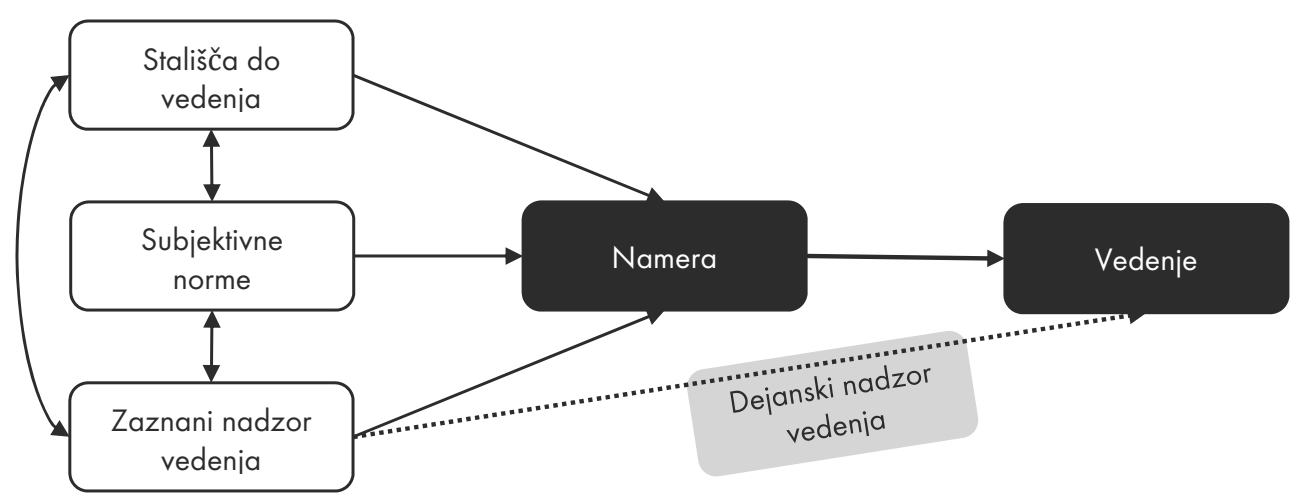

Vir: Ajzen (1991, str. 182)

Teorija načrtovanega vedenja ima še posebej pomembno vlogo pri raziskovanju sprejemanja tehnologije v kontekstu raziskav, ki vzpostavljajo povezave med kognicijo in posameznikovim vedenjem v različnih situacijah.

\section{Motivacijski model}

Motivacijski model (angl. Motivational model - MM) je široko razširjen in pogosto uporabljen za pojasnjevanje vedenja na podlagi klasične motivacijske teorije (Venkatesh, 2003), je pa tudi ena izmed temeljnih teorij pri raziskovanju sprejemanja in uporabe tehnologije. Ukvarja se z iskanjem dejavnikov, ki vplivajo na vedenje posameznikov in imajo motivacijski učinek.

Davis, Bagozzi in Warshaw (1992) v kontekstu motivacije za vedenje posameznika ločijo zunanjo in notranjo motivacijo. Zunanja motivacija se nanaša na situacijo, ko »uporabnik želi izvesti aktivnost, ker je ta dojeta kot uporabna pri doseganju želenega cilja (prav tam), a ni cilj že sama po sebi. Notranjo motivacijo pa definirajo (prav tam, 1992) kot dojemanje, kjer »uporabnik želi izvesti aktivnost brez dodatne spodbude in le zaradi samega procesa izvajanja aktivnosti $\ll$.

Zaradi lažjega merjenja notranje in zunanje motivacije za uporabo tehnologije so Davis idr. (1992) v dimenzijo notranje motivacije v modelu (glej Slika 9) vpeljali konstrukt dojemanje užitka (angl. perceived enjoyment), zunanjo motivacijo pa opredeljuje dojeta enostavnost uporabe (angl. perceived ease of use). 


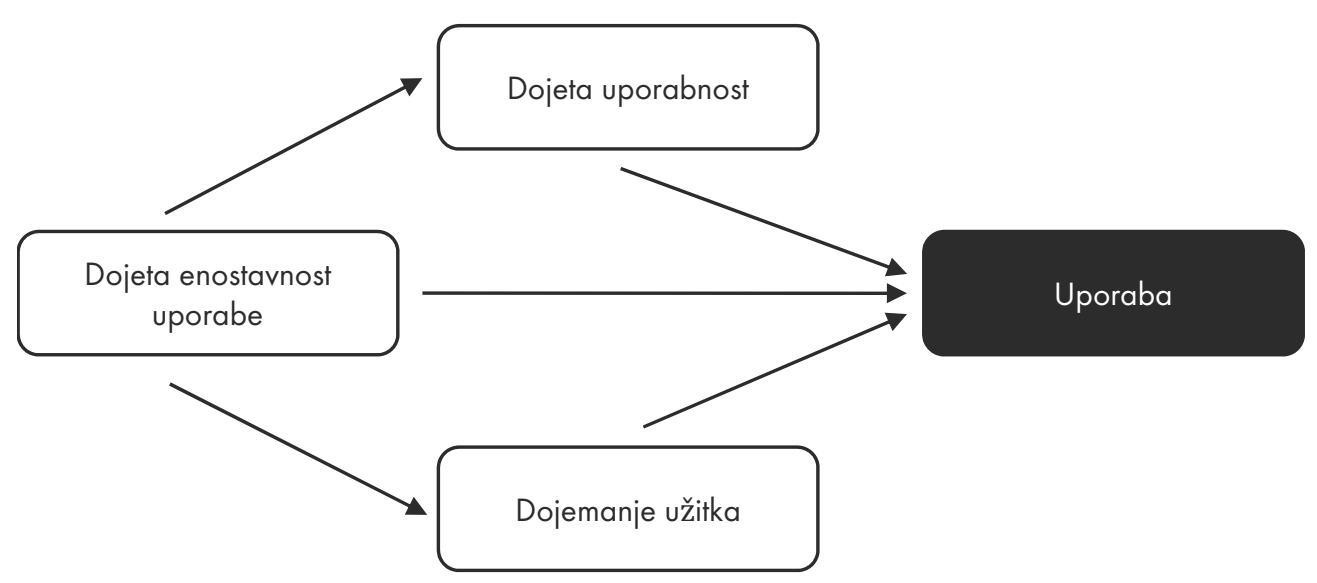

Vir: Venkatesh (2000, str. 357)

\section{Model uporabe osebnega računalnika}

Model uporabe osebnega računalnika (angl. The model of PC utilization - MPCU) temelji na teoriji medosebnega vedenja, katere avtor je Triandis (1977), po katerem je vedenje delno posledica namere, delno odzivov iz navade, delno pa tudi situacije same. $\mathrm{Na}$ namero vplivajo socialni in čustveni dejavniki, v enaki meri pa tudi premislek o nameri, medtem ko na vedenje vplivajo stališča, ki jih sicer uravnavajo čustveni zagon in kognitivne omejitve. Družbeni dejavniki v tem modelu zajemajo norme, družbene vloge in samopodobo, pri čustvenih dejavnikih pa gre za odzive posameznika, ki so onkraj razumnega premisleka o nameri za dejanje in so zato bolj ali manj nezavedni, pozitivni ali negativni, vsekakor pa so najbolj v ospredju pri instinktivnem odločanju o dejanju samem (Triandis, 1977).

Thompson je s sodelavci (Venkatesh, 2003) teorijo medosebnega vedenja prilagodil za namene napovedovanja sprejemanja in uporabe računalnika, vendar je model mogoče uporabiti tudi pri napovedovanju sprejemanja in uporabe tehnologije na splošno (prav tam). Model uporabe osebnega računalnika tako, v nasprotju s predhodno obravnavanimi teorijami in modeli, ki se osredotočajo na namero za dejanje, obravnava predvsem napovedovanje vedenja ( $v$ tem primeru uporabe računalnika oziroma tehnologije). Na uporabo računalnika po mnenju Thompsona, Higginsa in Howella (1991) vplivajo:

- družbeni dejavniki, kjer gre za vpliv kulture na mnenje posameznika, njegove norme in vrednote;

- čustva, ki se nanašajo na občutenja, bodisi pozitivna bodisi negativna, ob uporabi računalnika;

- kompleksnost uporabe, ki se nanaša na dojeto stopnjo zapletenosti razumevanja in uporabe računalnika; 
- ustreznost za delo, ki pomeni stopnjo posameznikovega prepričanja, da bo z uporabo računalnika izboljšal svoje delo;

- dolgoročne posledice uporabe računalnika, kjer posameznik »evalvira posledice vedenja $\mathrm{z}$ vidika morebitnih nagrad, svoje vedenje pa nato utemelji z željo po nagradi $\ll$;

- olajševalne okoliščine pri uporabi, ki so edina od posameznika neodvisna dimenzija in se nanašajo na objektivne dejavnike v okolju, ki olajšujejo rabo računalnika.

\section{Model TAM}

TAM (angl. Technology Acceptance Model) je kratica, ki označuje model za merjenje sprejemanja tehnologije, ki je najpogosteje uporabljen merski instrument na tem področju (Yousafzai, Foxall in Pallister, 2007). Avtor osnovnega modela TAM je Davis (1989), zasnoval pa ga je na temelju Fishbein-Ajzenove (1975) teorije utemeljene akcije, da bi razložil vzročno-posledično razmerje med prepričanji uporabnika, njegovim vedenjem, namero za uporabo in dejansko uporabo tehnologije (Yousafzai idr., 2007).

Davis (1989) je mnenja, da imata ključni vpliv na sprejemanje tehnologije dejavnika uporabnost in enostavnost uporabe. Mnoštvo drugih vplivov je opredelil kot zunanje dejavnike, ki imajo neposreden vpliv na dojeto uporabnost in enostavnost uporabe tehnologije.

Slika 5: Osnovni model TAM

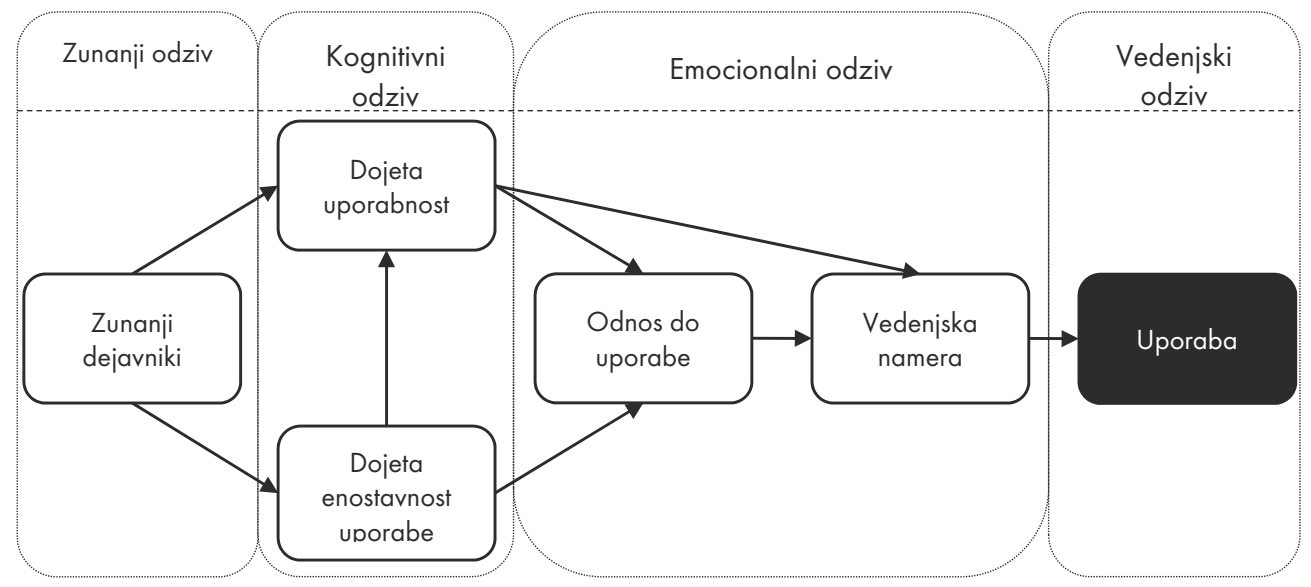

Vir: Davis, 1989

Dojeta uporabnost (angl. Perceived Usefulness) je definirana kot »stopnja, do katere posameznik verjame, da bo uporaba določenega sistema izboljšala njegovo delovno učinkovitost « (prav tam, str. 320), medtem ko je dojeta enostavnost uporabe (angl. Perceived ease of use) opredeljena kot »stopnja, do katere posameznik verjame, da uporaba 
določenega sistema ne bo terjala napora (prav tam, str. 320). Dojeta enostavnost uporabe vpliva na odnos do uporabe in nato še na vedenjsko namero prek mehanizmov samoocene in ocene uporabnosti, in sicer tako, da bolj ko posameznik neko tehnologijo dojema kot enostavno za uporabo, višja je njegova samoocena lastnih sposobnosti, s tem pa je višje ocenjena uporabnost tehnologije, hkrati pa velja še, da tem bolje ko je dojeta uporabnost tehnologije, bolj pozitiven odnos bo imel uporabnik do tehnologije (prav tam). Povedano drugače - če se tehnologija uporabniku zdi enostavna za uporabo, bo zaradi dojete enostavnosti višje ocenil lastne zmožnosti za uporabo in bo zaradi tega tehnologija zanj bolj uporabna, kot bi bila, če bi se mu ta zdela zapletena do stopnje, da je ne bi mogel uporabiti in mu zato ne bi koristila pri opravljanju določene naloge. Dojeta enostavnost uporabe je tako za avtorje sicer ključna, vendar ima še pomembnejši vpliv dojeta uporabnost tehnologije, saj lahko uporabnik navkljub zapletenosti tehnologijo uporablja, če bo z njo dosegel želeni cilj.

Ta teorija je botrovala široki uporabi modela za testiranje že uveljavljenih tehnologij, torej za razlago stopnje uporabe, kot tudi pri načrtovanju uporabe novih tehnologij $\mathrm{v}$ fazi razvoja oziroma za napovedovanje njihove uporabe. Prav zaradi številnih aplikacij modela pa so se pokazale tudi nekatere njegove slabosti. Bagozzi (2007) sicer glavno prednost TAM vidi v njegovi parsimoničnosti, vendar pa hkrati trdi, da je prav ta parsimoničnost njegova osrednja šibka točka, saj da ni možno pričakovati, da bo »tako enostaven [model, op. a.] v celoti pojasnil odločitve in vedenje pri tako širokem razponu tehnologij, situacij, različnosti v sprejemanju odločitev in tistih, ki te odločitve sprejemajo « (prav tam, str. 244). Konkretneje se njegova kritika nanaša na neposredno povezavo med namero za dejanje in dejanjem samim, kar je po njegovem mnenju nekritično sprejeta domneva, ki predvideva, da je dejanje oziroma vedenje že končni cilj delovanja, saj je praviloma uporaba tehnologije namenjena doseganju nekih drugih ciljev. Prav tako TAM zanemari dejansko koristnost uporabe tehnologije, moč posameznikovih prepričanj pri sprejemanju tehnologije, kompleksnost čustvenega doživljanja in vpliv širšega družbenega konteksta na sprejemanje odločitev. Bagozzi (prav tam) modelu očita determinističen pristop, ki zanemari možnost samoregulacije posameznika. Benbasat in Barki (2007) navajata, da se model intenzivno ukvarja z dojemanjem uporabnosti tehnologije, ob strani pa pušča iskanje razlogov, kaj neko tehnologijo dela uporabno.

Zaradi omenjenih pomanjkljivosti so različni avtorji TAM nadgradili v smeri večje kompleksnosti in vključili več dimenzij. Venkatesh in Davis (2000) sta osnovni model TAM razširila z vključitvijo novih dejavnikov (Slika 6), ki vplivajo na dojeto enostavnost uporabe in dojeto uporabnost, kar je $\mathrm{v}$ osnovnem modelu TAM opredeljeno kot zunanji dejavniki (Davis, 1989), ki so prvotno nemerljiva in predvsem zelo heterogena skupina vplivov. Pri zunanjih dejavnikih gre za vplive iz okolja in dejavnike, ki se nanašajo na kognitivne procese pri posamezniku (Venkatesh in Davis, 2000), vsi pa neposredno ali posredno vplivajo na dojeto uporabnost tehnologije. 
Slika 6: TAM2 - razširitev osnovnega modela TAM

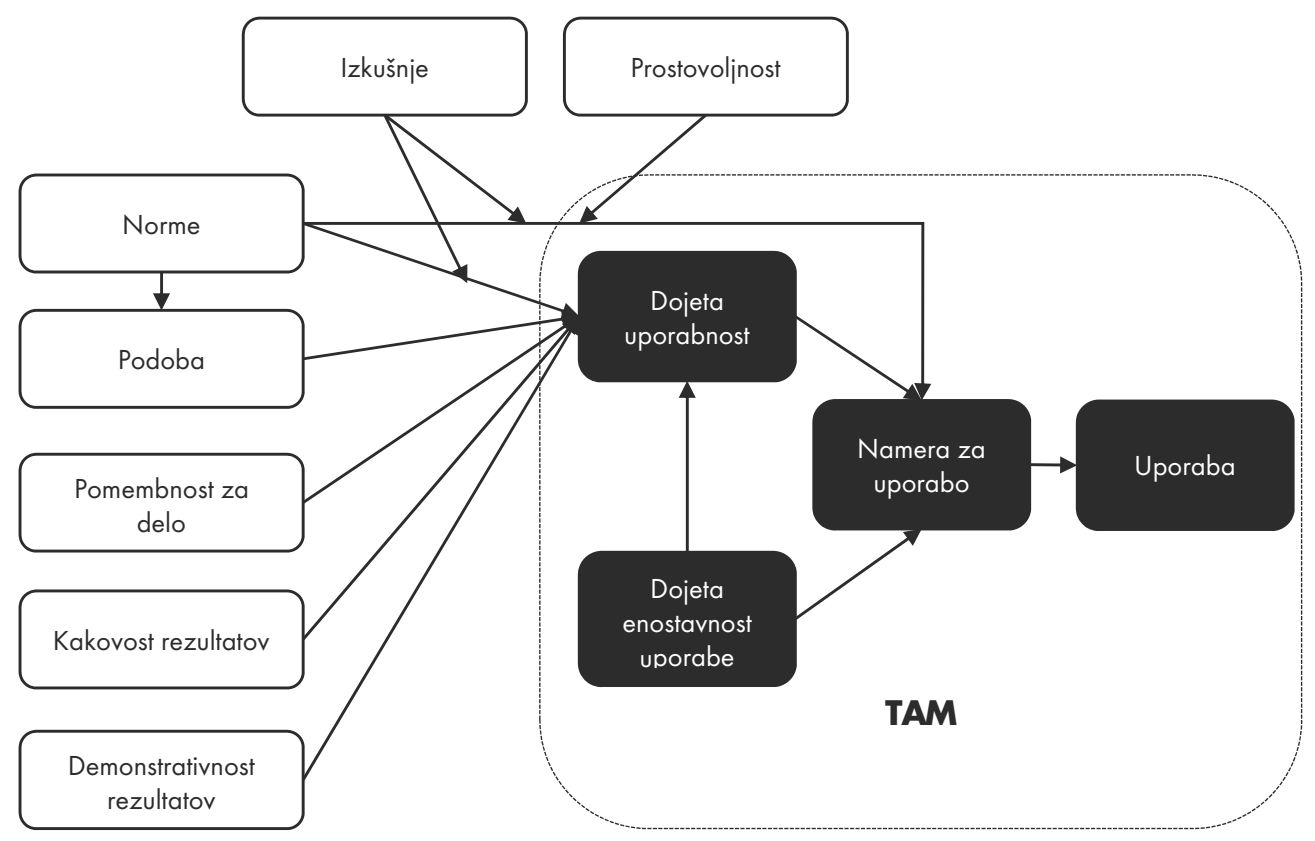

Vir: Venkatesh in Davis (2000, str. 197)

Med družbene dejavnike prištevata »tri medsebojno povezane družbene silnice, ki vplivajo na posameznikovo soočenje s priložnostmi za sprejem ali zavrnitev novega sistema: subjektivne norme, prostovoljnost in podobo « (prav tam, str. 187), kognitivne dejavnike pa opredelita kot posameznikovo »kognitivno primerjavo zmožnosti sistema s tistim, kar mora opraviti [z nalogo, op. a.]« (prav tam, str. 190), torej pomembnost za delo, kakovost rezultatov, demonstrativnost rezultatov in zaznano enostavnost uporabe. Posamezni dejavniki so opredeljeni v Tabeli 6 .

Kot je razvidno iz zgornje slike (Slika 6), se subjektivne norme povezujejo z namero za uporabo, in sicer prek posameznikovih izkušenj in prostovoljnosti uporabe, kjer velja, da tem višja ko so pričakovanja iz okolja in tem močnejša je prisila iz okolja, toliko bolj izražena bo tudi namera za uporabo. $\mathrm{K}$ temu dodatno prispevajo tudi posameznikove pretekle izkušnje.

Med bolj znane razširitve modela TAM sodi tudi model TAM3, ki je sicer razširjena različica modela TAM2. Venkatesh in Bala (2008) sta v model TAM3 vpeljala spremenljivke individualne razlike med posamezniki, kot so starost, spol in stopnja izobrazbe ter dojemanje zunanjega nadzora kot dejavnika vpliva na zaznano enostavnost uporabe; in čustvene dejavnike (strah pred računalnikom, veselje do dela $\mathrm{z}$ računalnikom ipd.) ter značilnosti tehnologije, ki prek posameznikovih izkušenj prav tako vplivajo na zaznano enostavnost uporabe. 
Tabela 6: Socialni in kognitivni dejavniki v modelu TAM2

\begin{tabular}{|c|c|c|}
\hline \multicolumn{2}{|c|}{ Dejavniki } & \multirow{2}{*}{$\begin{array}{l}\text { Opis } \\
\text { Posameznikova percepcija mnenja drugih liudi, } \\
\text { ki so zani pomembni, o uporabi tehnologije }\end{array}$} \\
\hline$\underset{\bar{z}}{\bar{z}}$ & Subjektivne norme & \\
\hline$\stackrel{\underline{u}}{\overline{\underline{Z}}}$ & Prostovoljnost & $\begin{array}{l}\text { Stopnja, do katere posameznik odločitev o } \\
\text { uporabi tehnologije zaznava kot neobvezno }\end{array}$ \\
\hline $\begin{array}{l}\bar{U} \\
\text { Oे }\end{array}$ & Podoba & $\begin{array}{l}\text { Stopnja, do katere uporaba tehnologije izboljša } \\
\text { status posameznika v družbeni skupini }\end{array}$ \\
\hline \multirow{4}{*}{ 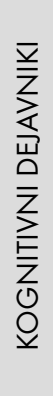 } & Pomembnost za delo & $\begin{array}{l}\text { Zaznana stopnja ustreznosti tehnologije za } \\
\text { opravljanje naloge }\end{array}$ \\
\hline & Kakovost rezultatov & Zaznana kakovost opravljene naloge \\
\hline & Demonstrativnost rezultatov & $\begin{array}{l}\text { Stopnja zaznanega prikaza rezultata opravlje- } \\
\text { nega dela }\end{array}$ \\
\hline & Dojeta enostavnost uporabe & $\begin{array}{l}\text { Stopnja, do katere posameznik dojema upora- } \\
\text { bo tehnologije kot nezapleteno, enostavno }\end{array}$ \\
\hline
\end{tabular}

Vir: Venkatesh in Davis (2000, str. 187-192)

\section{Model UTAUT}

Vse zgoraj obravnavane teorije ter modeli sprejemanja in uporabe tehnologije sestavljajo temelj, na katerem so Venkatesh, Moriss, Davis in Davis (2003) zasnovali enotno teorijo sprejemanja in uporabe tehnologije, kjer so združili dognanja vseh omenjenih teorij in modelov. Z obsežno metaanalizo že opravljenih empiričnih preverb slednjih so določili natančen okvir, ki ga opredeljujejo neodvisni konstrukti, povzeti iz teh teorij, s katerim lahko razložimo in napovedujemo vedenje uporabnikov ali spremljamo spreminjanje dejavnikov, ki vplivajo na vedenje uporabnikov tehnologije skozi čas uporabe.

Identificirali so štiri osrednje konstrukte in štiri stranske moderatorje, ki imajo pomemben vpliv na sprejetje in uporabo tehnologije (prav tam). 
Slika 7: Standardni model UTAUT

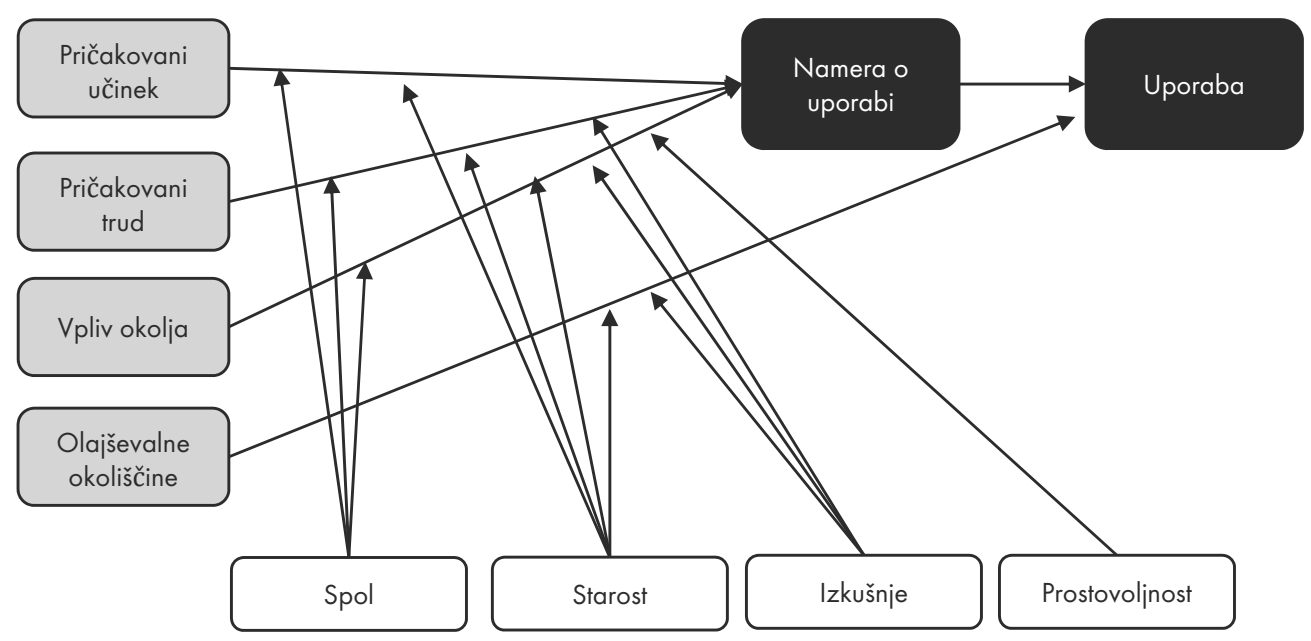

Vir: Venkatesh idr. (2003, str. 447)

\section{Konstrukti v modelu UTAUT}

Osrednji oziroma glavni konstrukti so tisti dejavniki, ki imajo neposreden vpliv na namero o uporabi oziroma na uporabo tehnologije. Konstrukt pričakovani učinek (angl. Performance Expectancy) kaže na »stopnjo, do katere posameznik verjame, da mu bo uporaba sistema pomagala pri doseganju večje učinkovitosti pri opravljanju naloge« (prav tam, str. 447). Ta konstrukt so avtorji zasnovali (prav tam) na Davisovem (1989) konstruktu dojete enostavnosti za uporabo (TAM), konstruktih zunanje motivacije (MM), ustreznosti za delo (MPCU), relativne prednosti (IDT) in pričakovanega izida (SCT). Pričakovani učinek je najpomembnejši kazalnik namere ne glede na to, ali je uporaba tehnologije prostovoljna ali ne.

Konstrukt pričakovani trud je opredeljen kot »stopnja enostavnosti uporabe « (prav tam, str. 450), torej v kolikšni meri je tehnologija za uporabnika še enostavna za uporabo. Ta dimenzija temelji na konceptih: dojeta enostavnost uporabe (TAM), kompleksnost uporabe (MPCU) in enostavnost uporabe (IDT).

Konstrukt vpliv iz okolja so avtorji (prav tam, str. 451) opredelili kot »stopnjo, do katere posameznik zaznava mnenje pomembnih drugih o svoji uporabi nove tehnologije «, vendar avtorji (prav tam, str. 452) opozarjajo, da so se vplivi iz okolja »izkazali kot pomembni le v začetnih fazah posameznikovega seznanjanja s tehnologijo«, s podaljševanjem časa uporabe pa se vpliv okolja na namero o uporabi tehnologije kaže kot nepomemben. To dimenzijo implicitno ali eksplicitno obravnavajo naslednji že omenjeni koncepti: subjektivne norme (TRA, TAM2, TPB), družbeni dejavniki (MPCU) in podoba (IDT). 
Olajševalne okoliščine so definirane kot »stopnja, do katere posameznik meni, da organizacijska in tehnična infrastruktura tehnologije omogoča njeno uporabo « (prav tam, str. 453), z drugimi besedami gre za mnenje posameznika o tem, ali ima na razpolago vse vire (orodja, opremo, znanje ipd.), ki jih potrebuje za uporabo nekega sistema. Konstrukt olajševalne okoliščine zajema naslednje koncepte: zaznani nadzor vedenja (TPB), olajševalne okoliščine (MPCU) in združljivost (IDT). Olajševalne okoliščine imajo neposreden vpliv na uporabo, ne pa tudi na namero o uporabi in posredno na samo uporabo, kot jo imajo preostali trije osrednji konstrukti.

Stranski oziroma podporni moderatorji v modelu UTAUT so starost, spol, izkušnje in prostovoljnost uporabe, ki nimajo neposrednega vpliva na namero ali uporabo tehnologije, vendar pa so $\mathrm{v}$ funkciji moderatorjev pri vplivu kognitivnih na vedenjske dejavnike. Tako avtorji (prav tam) ugotavljajo, da na pričakovani učinek posredno vplivata spremenljivki spol in starost, pri čemer imajo moški višja pričakovanja glede učinkov oziroma koristi, ki jih bo prinesla uporaba tehnologije, še posebej pa so pričakovanja visoka pri mlajših moških. Dalje tudi na pričakovanja vloženega truda posredno vplivata spol in starost, kjer so višja pričakovanja glede truda, vloženega v uporabo tehnologije, bolj značilna za ženske, prav tako pa imajo višja pričakovanja starejše populacije. Na ocene pričakovanega truda pa posredno vplivajo tudi pretekle izkušnje s tehnologijo. Na vplive iz okolja posredno vplivajo vsi stranski moderatorji, in sicer so zanje bolj dovzetne ženske, starejši in tisti, za katere uporaba tehnologije ni prostovoljna. Pri vplivu olajševalnih okoliščin na uporabo tehnologije se kot pomembna stranska moderatorja pojavita spremenljivki starost in izkušnje, in sicer višja stopnja olajševalnih okoliščin pri starejših posameznikih pomeni močnejši vpliv na uporabo kot pri mlajših; hkrati pa je vpliv olajševalnih okoliščin na uporabo tehnologije tem večji, tem več izkušenj ima posameznik z uporabo tehnologije.

Model UTAUT je v praksi doživel številne izvedbe v raziskavah, ki se ukvarjajo bodisi z vrednotenjem bodisi z napovedovanjem uporabe različnih tehnologij. Najpogosteje lahko model najdemo pri raziskovanju uporabe tehnologij na področjih storitvenih dejavnosti v kompleksnih družbenih sistemih, kot sta zdravstvo in šolstvo, pa tudi državna uprava, $\mathrm{v}$ zadnjem času pa tudi na področju uporabe aplikacij za mobilne telefone in tablične računalnike.

\section{ZAKLJUČEK}

Ne glede na to, ali menimo, da informacijska družba pomeni novo družbeno ureditev, ali pa smo prepričani, da gre le za še eno razvojno etapo industrijske družbe, razmah sodobnih informacijsko-komunikacijskih tehnologij nedvomno spreminja družbeno strukturo tako na ravni institucij kot tudi odnosov. V članku smo prikazali različne poglede na vlogo posameznika v razmerju med tehnologijo in družbo ter dejavnike, ki vplivajo na uporabo tehnologije. Ugotavljamo, da se s tehnološkim razvojem ustvarjajo nove oblike družbenega delovanja in interakcije ter $\mathrm{z}$ omejenim dostopom do teh tehnologij tudi nove družbene neenakosti. V kontekstu raziskovanja digitalnih razlik se kot rešitev za večjo 
uporabo e-gradiv kažejo trendi na področju »odprtega izobraževanja« in odprtih izobraževalnih gradiv (Dinevski in Radovan, 2013; Radovan, 2012). Kakovostni prosto dostopni viri za izobraževalne namene imajo lahko velik vpliv na zmanjševanje digitalnih razlik, predvsem pa je obravnava tega področja pomembna v razvitih družbah, kjer je materialni dostop do tehnologije relativno velik.

Osrednji del članka je bil namenjen predstavitvi empiričnih in teoretskih modelov, ki opisujejo dejavnike uporabe tehnologije na ravni posameznika. Ti modeli so za razumevanje uporabe IKT in spletnih aplikacij v izobraževanju izredno pomembni. V pomoč so lahko pri tehničnem prilagajanju te tehnologije, zlasti pa pri ustreznem izobraževanju/ usposabljanju uporabnikov teh tehnologij - v našem primeru učiteljev. Glavna značilnost predstavljenih teorij je njihova večdisciplinarnost - poleg tehnološkega vidika vključujejo tudi sociološke in psihološke dejavnike, ki vplivajo na sprejetost določene tehnologije. Na teorijah sprejemanja tehnologije so se razvili modeli, ki sprejemanje tehnologije najprej kvantificirajo, tako da postane to merljiv in primerljiv pojav, nato pa $\mathrm{z}$ iskanjem vzročno-posledičnih odnosov napovedujejo stopnjo sprejemanja konkretne tehnologije, kar je uporabno tako za identifikacijo vzrokov zavračanja tehnologije kot tudi za napovedovanje njene uporabe (Venkatesh idr., 2003).

V prihodnje bi bilo vsekakor potrebno v modele vključiti še pedagoške vidike e-izobraževanja, ki so pri klasičnih modelih preverjanja uporabe tehnologije povsem zanemarjeni. Pri dejanskem preverjanju učinkov uporabe oziroma izvajanja e-izobraževanja pa bi morali nujno prestopiti h vprašanju kakovosti izvajanja e-izobraževanja, kar je sicer ločeno področje in bi ga zato bilo problematično zvesti na koncept preverjanja določenega uporabniškega vedenja; povedano drugače - prisotnost določenega vedenja pri uporabi spletnih učilnic še ne pomeni točno določenega učinka vedenja. Vprašanje, ki bi ga bilo vredno raziskati v prihodnosti, je, ali so modeli sprejemanja in uporabe spletne učilnice kot tehnološke podpore pri izvajanju e-izobraževanja koristno orodje v fazi uvajanja e-izobraževanja, katerega namen je čim bolj razširiti uporabo spletne učilnice in vključenost v e-izobraževanje, ali tudi med samim procesom uporabe izobraževalne tehnologije, ki zadeva tudi pogostost uporabe in število učnih dejavnosti, ki se izvajajo.

Sklenemo lahko z ugotovitvijo prejšnjih raziskav, da lahko pogostejšo uporabo e-izobraževanja dosežemo že samo z vplivanjem na stališča uporabnikov (učiteljev) do uporabe (Parasuraman, 2000; Venkatesh idr., 2003; Yousafzai idr., 2007), kar bi nadalje imelo pozitiven učinek tudi na izvajanje e-izobraževanja in na njegovo kakovost. A kot rečeno, s kakovostjo e-izobraževanja že prehajamo na novo področje, ki si zasluži samostojno obravnavo.

\section{LITERATURA}

Ajzen, I. (1991). The theory of planned behavior. Organizational Behavior and Human Decision Processes, 50(2), 179-211.

Bagozzi, R. P. (2007). The Legacy of the Technology Acceptance Model and a Proposal for a Paradigm Shift. Journal of the Association for Information Systems, 8(4), 244-254. 
Bates, A. W. T. (2005). Technology, e-learning and distance education. London, New York: Routledge.

Benbasat, I. in Barki, H. (2007). Quo vadis, TAM?. Journal of the association for information systems, 8(4), 211-218.

Bijker, W. E., Hughes, T. P. in Pinch, T. (1987). The Social Construction of Technological Systems. Cambridge: MIT Press.

Bregar, L., Zagmajster, M. in Radovan, M. (2010). Osnove e-izobraževanja. Ljubljana: Andragoški center Slovenije.

Chandler, D. (1995). Technological or Media Determinism. Pridobljeno s http://www.aber.ac.uk/media/ Documents/tecdet/tecdet.html.

Colby, C. L. (2002). Techno-ready marketing of e-service: Costumers beliefs about technology and the implications of marketing e-services. V R. T. Rust in P. K. Kannan (ur.), e-Service: New directions in theory and practice (str. 25-44). Armonk, New York: M. E. Sharpe.

Davis, F. D. (1989). Perceived Usefulness, Perceived Ease of Use, and User Acceptance of Information Technology. MIS Quarterly, 13(3), 319-340.

Davis, F. D., Bagozzi, R. P. in Warshaw, P. R. (1992). Extrinsic and Intrinsic Motivation to Use Computers in the Workplace. Journal of Applied Social Psychology, 22(14), 1111-1132.

Dillon, A. in Moriss, M. G. (1996). User acceptance of information technology: Theories and models. V M. Williams (ur.). Annual review of information science and technology, 31 (str. 3-32). Medford, New Jersey: Information Today.

Dinevski, D. in Radovan, M. (2013). Adult Learning and the Promise of New Technologies. New Directions for Adult and Continuing Education, 138, 61-69.

Fischer, C. S. (1992). America calling: A social history of the telephone to 1940. Berkeley, Oxford: Universitiy of California Press.

Fishbein, M. in Ajzen, I. (1975). Belief, attitude, intention, and behavior: an introduction to theory and research. Reading: Addison-Wesley.

Haralambos, M. in Holborn, M. (2005). Sociologija: Teme in pogledi. Ljubljana: DZS.

Keengwe, J. in Kidd, T. T. (2010). Towards best practices in online learning and teaching in higher education. Journal of Online Learning and Teaching, 6(2), 533-541.

Krajnc, A. (2008). Odprtost dostopa do izobraževanja in e-učenje. Andragoška spoznanja, 14(3-4), 31-37.

McLuhan, M. (1964). Understanding Media: The Extensions of Man. New York: McGraw-Hill.

Nicholson, P. (2007). A history of e-learning: Echoes of the pioneers. V B. Fernandez-Manjon idr. (ur.), Computers and education: E-learning, from theory to practice (str. 1-11). Dordrecht: Springer.

Norris, P. (2001). Digital divide: civic engagement, information poverty, and the internet worldwide. Cambridge: Cambridge University Press.

Pannabecker, J. R. (1991). Technological impacts and determinism in technology education: Alternate metaphors from social constructivism. Journal of Technology Education, 3(1), 43-54.

Parasuraman, A. (2000). Technology Readiness Index (TRI) A Multiple-Item Scale to Measure Readiness to Embrace New Technologies. Journal of Service Research, 2(4), 307-320.

Petrovčič, A. (2011). Nove komunikacijske tehnologije in preoblikovanje družbenosti v pozni moderni (Doktorska disertacija). Ljubljana: Fakulteta za družbene vede.

Pinch, T. J. in Bijker, W. E. (1984). The social construction of facts and artefacts: Or how the sociology of science and the sociology of technology might benefit each other. Social Studies of Science, 14(3), 399-441.

Radovan, M. (2012). Digitalne razlike in e-izobraževanje. Andragoška spoznanja, 18(4), 37-44.

Rogers, E. M. (2003). Diffusion of innovations. New York: Free Press. 
Sheppard, B. H., Hartwick, J. in Warshaw, P. R. (1988). The theory of reasoned action: A meta-analysis of past research with recommendations for modifications and future research. Journal of consumer research, 15(3), 325-343.

Stefl-Mabry, J. (1999). Professional staff development: Lessons learned from current usability studies. Journal of Information Technology Impact, 1(2), 81-104.

Škerlep, A. (1998). Model računalniško posredovane komunikacije: tehnološka matrica in praktična raba v družbenem kontekstu. V V. Vehovar (ur.), Internet v Sloveniji (str. 24-53). Izola: Desk.

Thompson, R. L., Higgins, C. A. in Howell, J. M. (1991). Personal Computing: Toward a Conceptual Model of Utilization. MIS Quarterly, 15(1), 125-143.

Triandis, H. C. (1977). Interpersonal behavior. Monterey: Brooks/Cole.

Van Dijk, J. A. G. M. (2005). The deepening divide: Inequality in the Information Society. Thousand Oaks: Sage Publications.

Venkatesh, V. (2000). Determinants of Perceived Ease of Use: Integrating Control, Intrinsic Motivation, and Emotion into the Technology Acceptance Model. Information Systems Research, 11(4), 342-365.

Venkatesh, V. in Bala, H. (2008). Technology Acceptance Model 3 and a Research Agenda on Interventions. Decision Sciences, 39(2), 273-315.

Venkatesh, V. in Davis, F. D. (2000). A Theoretical Extension of the Technology Acceptance Model: Four Longitudinal Field Studies. Management Science, 46(2), 186-204.

Venkatesh, V., Morris, M. G., Davis, G. B. in Davis, F. D. (2003). User acceptance of information technology: Toward a unified view. MIS quarterly, 27(3), 425-478.

Williams, R. (2003). Television: Technology and Cultural Form. London in New York: Routledge Classics.

Yousafzai, S. Y., Foxall, G. R. in Pallister, J. G. (2007). Technology acceptance: a meta-analysis of the TAM: Part 1. Journal of Modelling in Management, 2(3), 251-280. 